УДК $374.72: 159.9$

Пічугіна Ірина Сергіївна

аспірант

Інститут інформаційних технологій і засобів навчання НАПН України, м. Київ, Україна

Iryna_ryna@mail.ru

\title{
ОСОБЛИВОСТІ ВИКОРИСТАННЯ ВЕБІНАРІВ ДЛЯ РОЗВИТКУ ДУХОВНО-МОРАЛЬНИХ ЦІННОСТЕЙ У НЕФОРМАЛЬНІЙ ОСВІТІ ДОРОСЛИХ
}

\begin{abstract}
Анотація. Метою цієї роботи є розгляд особливостей застосування вебінарів для розвитку духовно-моральних цінностей в неформальній освіті дорослих. Актуалізація проблеми формування духовності пов'язана із сучасними вимогами до моральних якостей дорослих, що випливає 3 їх особливої функції в суспільстві щодо можливостей впливати на формування і становлення духовних цінностей підростаючого покоління. Проведення психолого-педагогічних семінарів, лекцій, консультацій для дорослих щодо особистих проблем, які виникають внаслідок непорозуміння або втрати головних моральних якостей людини, у режимі on-line $\epsilon$ актуальним і затребуваним. Формою такого спілкування пропонується розглянути вебінар як один 3 інструментів застосування інформаційнокомунікаційних технологій в неформальній освіті дорослих.
\end{abstract}

Ключові слова: вебінар; духовно-моральні цінності; неформальна освіта; освіта дорослих; психологічне консультування; психологічний семінар.

\section{1. ВСТУП}

Постановка проблеми. У сучасному суспільстві спостерігається слабкий прояв, втрата духовно-моральних людських якостей як серед дорослих, так і серед молоді. На нашу думку, це є наслідком недостатньої уваги до виховного процесу підростаючого покоління, яке за тенденцією руху часу, через декілька років позиціонує себе поколінням дорослих людей. Виховання є духовною серцевиною освіти [3]. Оскільки для молоді доросла людина є зразком поведінки, свідомим або несвідомим вихователем у статусі батьків, педагогів або інших авторитетних особистостей, вважаємо розвиток духовно-моральних якостей дорослих значущим аспектом зростання духовності у суспільстві в цілому.

На нашу думку, реалізувати даний аспект можливо шляхом неформальної освіти дорослих. На даний час в Україні існування неформальної освіти охоплює такі галузі: позашкільна освіта; післядипломна освіта та освіта дорослих; громадянська освіта (різнопланова діяльність громадських організацій); шкільне і студентське самоврядування (через можливість набуття управлінських, організаторських, комунікативних та ін. умінь); освітні ініціативи, спрямовані на розвиток додаткових умінь і навичок (комп'ютерні та мовні курси, гуртки за інтересами тощо). Останнім часом розпочали роботу кілька університетів третього віку, що надають освітні послуги старшим особам [4]. Також одним із сегментів неформальної освіти є спонтанна освіта, яка ініціюється безпосередньо особистістю.

Враховуючи сучасні можливості інформаційно-комунікаційних технологій і їх застосування в освіті, необхідним є вивчення особливостей використання вебінарів, як однієї з форм вищезазначених технологій, у неформальній освіті дорослих, що може тривати продовж всього життя, тобто виступати інструментом постійного самовдосконалення. Визначена проблема сприяє вивченню різноманітних форм i 
особливостей неформальної освіти дорослих, розгляду особливостей застосування online навчання і його результатів.

Аналіз останніх досліджень та публікацій. На жаль, зазначена проблема не повною мірою і в недостатньому обсязі висвітлена в наукових джерелах. Їх аналіз показав вивчення лише окремих питань проблеми, що розглядається у статті.

Розв'язання цієї проблеми вже частково розпочато деякими вченими i відображено в їхніх дослідженнях. Так, питанням неформальної освіти як процесу безперервного навчання та освіті дорослих присвячені праці: Гусейнової Е. I. [4], Лук'янової Л. Б. [7-8], Нестеренко Г. О., Тишкової О. В. [12]. Проблеми взаємозв’язку освіти, педагогічної праці з духовною культурою вивчають у своїх дослідженнях Волченська Т. В. [3], Ткачова Т. М. [15]. У публікаціях Писклярової А. В., Мацко Л. А. [13], Булави Ю. Л. [2] розглядаються різноманітні форми інформаційно-комунікаційних технологій у психологічній роботі. А Мигович С. М.[9] приділяє увагу формуванню освітньо-інформаційного середовища. Праці Клейно Л. Г., Гринько В. О. [5], Царенко В. О. [16], Морзе Н. В., Ігнатенко О. В. [11] зосереджені на вивченні Вебінару як технології навчання.

Але вищезазначені дослідники не поєднують у своїх працях питання, що сформульовані як проблема даної статті. Тобто не розглядається сукупність застосування описаних методів, технологій, прийомів, моделей, можливостей щодо розв'язання проблеми, яка вивчається у нашому дослідженні. Тому вважаємо доцільним поєднати в даній статті окремі аспекти, що вивчаються іншими дослідниками.

Мета статті - проаналізувати основні напрями роботи психолога і виявити такі, що дозволяють здійснювати просвітницьку і навчально-виховну діяльність у рамках неформальної освіти дорослих; розглянути поняття «Вебінар»; визначити особливості використання Вебінарів 3 метою проведення психологічної роботи у напрямку просвітницької і навчально-виховної діяльності у вигляді семінарів і тренінгів для розвитку духовно-моральних цінностей у неформальній освіті дорослих.

\section{2. МЕТОДИ ДОСЛІДЖЕННЯ}

В ході дослідження використовувались наступні методи: аналіз теоретичних джерел щодо проблем використання Вебінару у неформальної освіти дорослих, щодо проблем розвитку духовної культури; вивчення та узагальнення досвіду застосування інформаційно-комунікаційних технологій педагогами та практичними психологами при роботі з дорослими.

\section{3. РЕЗУЛЬТАТИ ДОСЛІДЖЕННЯ}

Проблеми розвитку духовно-моральних цінностей, їх відродження набувають сьогодні актуальності. Погоджуємося $з$ думкою Волченської Т. В. [3], що розуміння необхідності духовно-морального оздоровлення соціального життя стає характерним для масової суспільної свідомості.

Сучасній соціокультурній ситуації в країні притаманні тенденції зростання бездуховності, що проявляється як у відношенні до життєвих проблем, до культури, до освіти, так і в поведінці, у людських взаємовідносинах. Деморалізаційні процеси в суспільстві, криза духовності, культ легких грошей і задоволень, які до цього ж нав'язуються засобами масової інформації, створили ускладнену ситуацію у вихованні i розвитку моральних цінностей [3]. 
Особлива необхідність зосередити увагу саме на формуванні духовності викликана й диспропорцією, що виникла останнім часом між освітою і вихованням. Виховання, як духовна серцевина освіти, принесено «в жертву миттєвим прагматичним інтересам». Наслідком цього стала втрата цілого покоління молоді, що з'явилось, обділених моральними цінностями і яке не $\epsilon$ взмозі отримати можливості прилучатися до відповідального розуміння сенсу людського життя. Тому, так гостро встала проблема формування і розвитку духовних і моральних цінностей дорослих, які здатні допомогти сучасної молоді: своїм дітям, підростаючому поколінню усвідомити і керуватися в житті загальнолюдськими цінностями [3].

Посилаючись на публікації Волченської Т. В. [3], скажемо, що актуалізація проблеми формування i розвитку духовності пов'язана 3 новими вимогами до моральних якостей дорослих, що випливає з їх особливої функції в суспільстві щодо сімейних, соціальних, громадянських можливостей впливати на формування i становлення духовного життя молоді, на моральні процеси життєдіяльності підростаючого покоління. Коли втрачається стійкість цінностей, здійснюється їх переоцінювання, ломка і зміна, стає особливо важливим зосередження уваги на неформальній освіті дорослих.

Неформальна освіта $є$ важливим елементом у процесі створення демократичного суспільства, вихованні громадянина [1]. На думку Білоус I. [1], аналіз сучасних наукових джерел засвідчує, що у педагогічній науці немає однозначного трактування терміна "неформальна освіта".

Неформальну освіту розуміють, по-перше, як будь-яку навчальну діяльність у робочий чи позаробочий час у колі фахівців, друзів, родини, що не є структурованою, організованою чи спланованою; по-друге, як навчальний процес, що відповідає структурі цієї діяльності, набуває організованої форми, не належить до державних програм обов 'язкової освіти і визначається цілеспрямованістю. Зазначена форма освіти не завжди передбачає видачу сертифікатів, посвідчень, що засвідчують рівень одержаної кваліфікації після ії завершення [1].

За Гусейновою Е. І., неформальна освіта - освіта, що необов'язково має організований i систематичний характер, може здійснюватися поза межами організованих освітніх закладів. До сфери неформальної освіти належать індивідуальні заняття під керівництвом тренерів чи репетиторів, тренінги та короткотермінові курси, що переслідують практичні короткострокові цілі. Неформальна освіта не має вікових, професійних чи інтелектуальних обмежень щодо учасників, нерідко не обмежується часовими рамками. Заклади чи організації, що займаються неформальною освітою, зазвичай, не присуджують кваліфікацій і не провадять формального оцінювання навчальних досягнень учасників. У цьому секторі найчастіше застосовують інноваційні підходи, апробують новаторські методики і технології навчання [4].

Проблема розвитку і виховання духовності $\epsilon$ однією 3 центральних проблем сучасних педагогіки і психології. В основі процесу духовного виховання науковці бачать формування в особи прагнення до найвищих загальнолюдських цінностей: гуманістичних ідеалів злагоди, милосердя, правди, справедливості; переважання альтруїстичних мотивів, готовності поступитися власними інтересами заради інтересів інших; потреби безкорисно робити добро і триматися далі від зла. Ступінь розвиненості цих рис особистості свідчить про рівень иї духовності [17].

За визначенням у Педагогічному словнику [6], духовне виховання - це формування ціннісного відношення до життя, що забезпечує стійкий / сталий та гармонійний розвиток людини. Це виховання почуття обов'язку, справедливості, щирості, відповідальності та інших якостей, здатних надати вищий сенс справам i думкам людини. 
Погоджуємося 3 Ягуповим В. В., що моральне виховання - це цілеспрямоване формування моральної свідомості, розвиток морального почуття й формування звичок i навичок моральної поведінки людини відповідно до певної ідеології. Воно залежить від моралі - однієї з форм суспільної свідомості, сукупності загальноприйнятих норм, принципів і правил, що регулюють поведінку людей [19, с. 267].

У сучасному культурно-освітньому просторі поняття “духовність”, “духовна культура" активно вводяться в навчальний і методичний процеси. Основою духовного зростання підростаючих поколінь, професійно-педагогічної успішності педагогів стає адекватне розуміння духовності й заснований на ньому розвиток духовної культури $[15$, c. 3$]$.

Одним із напрямків педагогічної роботи є психологічна діяльність, що включає такі основні види діяльності практичного психолога:

- просвітницько-пропагандистська робота;

- пропедевтична і профілактична робота;

- психологічне консультування;

- психодіагностика і прогностика;

- психокорекція, психотерапія та соціально-психологічна реабілітація [10].

Як правило, внаслідок заходів, здійснених практичним психологом, незалежно від виду його діяльності, виявляється багатокомпонентний ефект, що дозволяє клієнту отримати нові знання, тобто здійснюється просвітницький ефект [10]. Формами надання нових знань $є$ лекції, семінари, роз'яснення, консультування, у результаті чого відбувається процес неформальної освіти дорослих, що сприяє їх саморозвитку i вдосконаленню.

Необхідність диференціації й індивідуалізації навчання, просвіти, застосування новітніх методів виховання, стимулювання саморозвитку і самоосвіти особистості залучає психолога до навчально-виховного процесу, що є однією з форм безперервної освіти - самоосвіти дорослих [14]. Можна зазначити, що кваліфікація дорослих, що була здобута під час формальної освіти, не має значення для того, щоб розвивати свої духовно-моральні якості у рамках неформальної освіти. Клієнт, якому практичний психолог надає послуги консультування, роз'яснення або проводить лекції чи семінари, уже впливає під навчально-виховний і просвітницький процес.

Основний принцип діяльності освітніх систем розвинених країн - це залучення громадянина до навчання, яке триває постійно, усе життя. Розвиток неперервного навчання разом із формуванням суспільства знань став одним із соціальних наслідків глобалізації й інформатизації. Освіта більше не може обмежуватися кількома роками чи навіть десятиліттями на початку життя людини, оскільки безперервне оновлення інформації вимагає постійного самовдосконалення i навчання для досягнення життєвого успіху [4].

Тим більше, що саме неформальна освіта набуває все більшої актуальності в умовах безперервного пізнавального процесу. У центрі уваги стоїть високоосвічена особистість, яка докладає зусилля не тільки до власного розвитку, а й до розвитку суспільства [12].

Як зазначає Ткачова Т. М. [15, с. 10] у своїх дослідженнях, у розвитку духовної культури дорослого важливе значення має психофізіологія мотивації, потребнісномотиваційна основа розвитку духовної культури особистості; і могутньої сили набуває саморозвиток, спрямовуюча сила творчого потенціалу особистості.

Тобто, будь-яка доросла людина, що вирішила йти шляхом самовдосконалення через звернення до психолога, спонтанно потрапляє до процесу неформальної освіти. Тим самим, отримуючи необхідну інформацію, самостійно, але за допомогою 
психолога, виховує в собі відсутні або посилює слабкі духовно-моральні якості, завдяки яким вирішує життєві питання.

У даний час бурхливий розвиток інформаційних технологій впливає на стиль і методологію роботи практикуючих психологів. Професійна діяльність психолога $\epsilon$ по суті інформаційною діяльністю, що включає в себе здатність цілеспрямовано працювати 3 інформацією на всіх етапах іï отримання, обробки, зберігання, передавання [2, с. 24].

Головна роль у процесі роботи практичного психолога 3 особистістю $\epsilon$ спілкування. Клейно Л. Г., Гринько В. О. [5] визначають спілкування як багатоплановий процес встановлення і розвитку контактів між людьми, що спрямовані на обмін інформацією, сприймання і розуміння іншого, орієнтуючись на певну тактику і стратегію взаємодії.

Інформатизація соціального простору ініціює появу нових форм спілкування і комунікації - електронної комунікації, що призводить до зміни характеру і форм сучасної комунікації.

Проаналізувавши діючі напрями, що відкриває сучасне комп'ютерно орієнтоване середовище для спілкування, у тому числі і для цільового спілкування, що може здійснюватись 3 метою саморозвитку дорослих, зазначимо великий спектр альтернативного вибору:

1) за системою навчання: навчальні центри, курси, тренінгові групи, Інтернетспівтовариства, групи соціальних мереж;

2) за методом навчання: дистанційне навчання; навчання по Skype; WEBконференції; WEB-семінари; спілкування в соціальних мережних групах.

У такому форматі практичному психологу можна організовувати і координувати індивідуальну і групову просвітницьку, консультаційну роботу з дорослими, у вигляді психологічних семінарів, тренінгів на рівні неформальної освіти і самоосвіти [9].

На нашу думку, психологічний семінар — це одна з основних форм педагогічної, просвітницької роботи, що сприяє досягненню високого рівня моральної i психологічної культури, створення певного настрою щодо розвитку у слухачів духовно-моральних цінностей.

Психологічний тренінг — це форма активного навчання, яка дозволяє людині самоформувати навички й уміння в побудові продуктивних психологічних і соціальних міжособистісних відносин, аналізувати соціально-психологічні ситуації зі своєї точки зору і позиції партнера, розвивати в собі здібності пізнання і розуміння себе й інших у процесі спілкування [13].

Фахівець психологічного профілю в сучасних умовах повинен правильно використовувати інформаційні ресурси - вирішувати за допомогою знань, отриманих у сфері інформаційних технологій, питання, що виникають у психологічній практиці; володіти на високому рівні технологіями доступу до локальних і глобальних мережевих інформаційних ресурсів; знати основні тенденції розвитку сучасних інформаційних технологій і їх потенційне застосування у психологічній практиці [2, с. 24].

Розглянемо поняття «Вебінар», що надається у кількох варіантах.

1) Вебінар (від англ.web+seminar, webinar) — це віртуальний семінар, що організований за допомогою інтернет-технологій [16].

2) Вебінар - як новий формат навчання, який передбачає проведення занять у режимі реального часу на основі сучасних технологій зв'язку, що забезпечують передавання аудіовізуальної інформації [16].

3) Вебінар як технологія, що дає можливість повною мірою відтворити умови колаборативної (спільної) форми організації навчання, a саме семінарських i лабораторних занять, лекцій тощо [11]. 
4) Вебінар (від англійської «Webinar», скорочення від «Web-basedseminar») — онлайн-семінар, який надає можливість ведучому (тренеру, консультанту, професіоналу, учителю) передавати інформацію (досвід, знання, уміння, завдання), а учасникам отримувати інформацію і навчатися за допомогою віртуального класу, у якому є можливість чути і бачити один одного, де б ви не знаходились [18].

Такі віртуальні класи можуть стати «віртуальним майданчиком», неформальною аудиторією, де проводиться накопичення, формалізація неявного знання, що розширює можливості інформаційно-комунікативних технологій у контексті розвитку неформальної освіти [9].

Зазвичай, практичний психолог може проводити заняття в режимі лекції, семінару 3 трансляцією навчальних матеріалів. Вебінар має всі переваги традиційного семінару, відтворюючи можливості особистого спілкування між слухачами, а також живого спілкування між слухачами і доповідачем, зазначено у публікації [5]. Зворотній зв'язок зі слухачами може проходити в режимі чату або голосового спілкування.

Залежно від мети і завдань психологічної роботи форма навчання або виховання може відбуватися за допомогою Вебінару і розкривати додаткові переваги застосування інформаційно-комунікаційних технологій.

1. Для проведення занять 3 викладання відповідної тематики, де поряд iз класичною академічною інформацією можуть використовуватися: електронні довідники, електронні словники, електронні бібліотеки та різні пошукові системи.

2. На етапі надання слухачам навчальної інформації, а також у процесі іiі подальшої актуалізації й аналізу слухачами, де поряд можуть бути використані: електронні презентації, електронні посібники, розсилання необхідної інформації.

3. На етапі надання слухачами результатів засвоєння навчального матеріалу й оцінювання викладачем-психологом ступеня засвоєння матеріалу можливі такі варіанти використання: електронні телеконференції, форуми, презентації.

4. На етапі обміну досвідом між слухачами, з психологом ефективним з'являється використання дистанційних телеконференцій, обговорення результатів на форумі, on-line психологічних тренінгах [2, с. 24-25].

Також, погоджуємось 3 думкою Булави Ю. Л. [2, с. 25], що використання інформаційних технологій у процесі навчання дозволяє об'єднати реалізацію академічних, професійних компетенцій (знання, уміння, навички 3 теми, що вивчається), і здатність застосовувати їх у повсякденному житті, у тому числі у професійній, соціальній, культурній, громадській діяльності.

Інформаційні технології не тільки надають можливості для отримання дорослим учням необхідної інформації, але й створюють умови для демонстрації результатів роботи самих слухачів.

Отже, можна виділити деякі особливості використання Вебінарів для розвитку духовно-моральних цінностей у неформальній освіті дорослих:

- по-перше, за допомогою Вебінару здійснюється спілкування, завдяки чому можливо обмінюватись інформацією, сприймати і розуміти один одного. Тобто вихователь (у нашому випадку це психолог) може встановлювати взаємодію 3 вихованцем (у нашому випадку це клієнт психолога - будь-яка доросла людина), орієнтуючись на певну тактику і стратегію;

- по-друге, у форматі віртуального класу, що надає Вебінар, можлива не тільки аудіо-, але й візуальне передавання інформації, що можна використовувати для створення особливих умов, що сприятимуть вихованню і розвитку духовноморальних цінностей дорослих; 
- по-третє, згодні з Булавою Ю. Л. [2, с. 25], що саме завдяки використанню інформаційних технологій можна не тільки продемонструвати інформацію через презентації, форуми, пересилку документів, але й отримати зворотній зв'язок щодо виконаної роботи від вихованців, поділитися досвідом, беручи участь у Вебінарах, форумах 3 тематичних питань, й так забезпечити двосторонній процес обміну інформацією. Тобто, відбувається повноцінний навчальний, виховний та просвітницький процес.

Тому, використання інформаційних технологій є дуже плідним й ефективним у роботі практичних психологів [2, с. 25]. I саме використання Вебінарів у психологопедагогічній діяльності створює умови для розвитку духовно-моральних цінностей дорослих у процесі неформальної освіти.

\section{4. ВИСНОВКИ ТА ПЕРСПЕКТИВИ ПОДАЛЬШИХ ДОСЛІДЖЕНЬ}

Отже, шляхом аналізу основних напрямків роботи психолога виявлено можливість здійснення просвітницької і навчально-виховної діяльності у рамках неформальної освіти дорослих, що дозволяє розвивати морально-духовні цінності дорослих за умови їх прагнення до самовдосконалення.

Розглядаючи поняття «Вебінар», з'ясовано, що така технологія створює віртуальну неформальну аудиторію для повноцінного навчання.

Визначено особливості використання Вебінарів 3 метою розвитку духовноморальних цінностей у неформальній освіті дорослих шляхом проведення психологічної роботи у напрямку просвітницької і навчально-виховної діяльності у вигляді семінарів і тренінгів. Оскільки, саме дорослі слухачі відповідних Вебінарів, зацікавленні у самовдосконаленні, вони зможуть осягнути пріоритетність духовних $\mathrm{i}$ моральних цінностей спочатку у своєму житті і стануть відповідальними за моральне самовизначення, розвиток свого духовного світу, а потім, у майбутньому зможуть передати свій духовний досвід молоді.

Наступні дослідження варто спрямувати для розгляд й аналіз існуючого програмного забезпечення для проведення психолого-педагогічних Вебінарів.

\section{СПИСОК ВИКОРИСТАНИХ ДЖЕРЕЛ}

1. Білоус І. Чи потрібна Україні неформальна освіта? [Електронний ресурс] / Білоус I. // Студентський інтернет-журнал «Освіта та ...». - Режим доступу : http://osvitata.com/osvita-tasuspilstvo/chi-potribna-ukra-ni-neformalna-osvita.html. — Дата доступу 19.09.2014.

2. Булава Ю. Л. Информационные технологии в преподавании дисциплін психологического профиля / Булава Ю. Л. / Использование информационных образовательных технологий и электронных средств обучения в вузе: материалы науч.-метод. конф. / ответственный редактор В. А. Снежицкий. - Гродно : ГрГМУ, 2011. - С. 23-26.

3. Волченська Т. В. Формирование духовности учителя [Електронний ресурс] / Т. В. Волченська / Інноваційна професійно-технічна освіта: Пошуки шляхів оновлення : матеріали III Всеукраїнської науково-практичної інтернет-конференції, присвяченій 20-річчю НАПН України (26-30 березня 2012 р.). - УМО-Інститут післядипломної освіти інженерно-педагогічних працівників. Донецьк, 2012. - 340 с. — Режим доступу : http://kafpppo.narod.ru/user-files/conference2012.pdf. — Дата доступу 23.03.2014.

4. Гусейнова Е. I. Неформальна освіта як важливий елемент безперервної освіти [Електронний peсурс] / Гусейнова Е. І., Лук'янова Ю. М. // Педагогические науки: Стратегические направления реформирования системы образования. - Сумський національний аграрний університет, 2012. Режим доступу : http://www.rusnauka.com/11_NPE_2012/-Pedagogica/4_106261.doc.htm. — Дата доступу 09.09.2013.

5. Клейно Л. Г. Можливості та особливості проведення вебінарів [Електронний ресурс] / Клейно Л. Г., Гринько В. О. // Научный журнал «Аспект» - Международные научно-практические 
конференции 2014 - Державний вищий навчальний заклад «Донбаський державний педагогічний університет». - Слов'янськ — Режим доступу : http://asconf.com/rus/index. — Дата доступу 20.03.2014.

6. Коджаспірова Г. М. Педагогический словарь : для студентов высш. и сред. пед. учеб. завед. / Коджаспирова Г. М., Коджаспиров А. Ю. - 2-е изд. - Москва : Академия, 2005. - 176 с.

7. Лук'янова Л. Б. Провідні особливості навчання дорослих / Л. Б. Лук'янова // Освіта дорослих: теорія, досвід, перспективи : зб. наук. праць. - К. : ІПООД АПН України, 2009. — Вип. 1. — С. 97.

8. Лук'янова Л. Б. Соціокультурна функція освіти дорослих у сучасному суспільстві / Л. Б. Лук'янова // Вісн. Черкас. ун-ту. Сер. Пед. науки. - 2010. - Вип. 183, ч. 1. - С. 6-12.

9. Мигович С. М. Роль і місце соціальних мереж у формуванні освітньо-інформаційного середовища аграрних університетів: стаття / Мигович С. М., Тверезовська Н. Т. // Науковий вісник НУБіП серія «Педагогіка, психологія, філософія». - Випуск 175, частина 3. - Київ, 2012. http://www.mnau.edu.ua/ua/02_02_01_10_mygovich.-html\#ixzz2wnSKAKKp.

10. Місце психології в системі людинознавства [Електронний ресурс] / Вебсайт. - Режим доступу : http://ua.convdocs.org/docs/index-184148.html. — Дата доступу 23.03.2014.

11. Морзе Н. В. Методичні особливості вебінарів, як інноваційної технології навчання / Н. В. Морзе, О. В. Ігнатенко // Інформаційні технології в освіті: зб. наук.пр. - Херсон : ХДУ, 2010. — Вип. 5. - C. 31-39.

12. Нестеренко Г. О. Сучасні соціальні мережі як інструмент неформальної освіти / Нестеренко Г. О., Тишкова О. В. // Гілея. Науковий вісник. - Випуск 49 (№7). — 2011. — С. 451-458.

13. Писклярова А. В. Психологічний тренінг як інноваційний метод виховної роботи у Вищому навчальному закладі [Електронний ресурс] / Писклярова А. В., Мацко Л. А. / Вінницький національний технічний університет. - Режим доступу

http://conf.vntu.edu.ua/humed/2010/txt/Pysklyarova_Matsko.php. — Дата доступу 22.03.2014.

14. Практична психологія як наукова дисципліна [Електронний ресурс] / Вебсайт. - Режим доступу : http://knowledge.allbest.ru/psychology/2c0b65635b2bd68b4d53b88521216d27_0.htm. — Дата доступу 22.03.2014.

15. Ткачова Т. М. Розвиток духовної культури особистості вчителя в системі методичної роботи закладів освіти міста : автореф. ... к. пед. н. / Т. М. Ткачова ; Луганський Національний педагогічний університет імені Тараса Шевченка. - Луганськ, $2004-23$ с.

16. Царенко В. О. Вебінар як технологія навчального співробітництва учнів і вчителів середніх шкіл / Царенко В. О. // Інформаційні технології в освіті : зб. наук. праць. - Херсон : ХДУ, 2011. — Вип. 9. - C. 89-93.

17. Шевченко О. В. Духовне виховання у сучасній сім’ї [Електронний ресурс] / Шевченко О. В. // Вебсайт: www/ VuzLib.com. - Режим доступу : http://vuzlib.com/content/view/968/94. — Дата доступу 10.09.2014.

18. Що таке Вебінар? / Технології Веб 2.0 // Режим доступу : http://web2.in.ua/2010/01/18/scho-takevebinar.html. - Дата доступу 18.03.2014.

19. Ягупов В. В. Педагогіка: навч. посіб. / Ягупов В. В. - К. : Либідь, 2002. - 560 с. [Електронний pecypc]. — Режим доступу : http://eduknigi.com/ped_view.php?id=267. — Дата доступу: 10.09.2014.

Матеріал надійшов до редакиї 21.09.2014 p.

\title{
ОСОБЕННОСТИ ИСПОЛЬЗОВАНИЯ ВЕБИНАРОВ ДЛЯ РАЗВИТИЯ ДУХОВНО-НРАВСТВЕННЫХ ЦЕННОСТЕЙ В НЕФОРМАЛЬНОМ ОБРАЗОВАНИИ ВЗРОСЛЫХ
}

\author{
Пичугина Ирина Сергеевна \\ аспирант \\ Институт информационных технологий и средств обучения НАПН Украины, г. Киев, Украина \\ Iryna_ryna@mail.ru
}

Аннотация. Целью данной работы является рассмотрение особенностей использования вебинаров для развития духовно-моральных ценностей в неформальном образовании взрослых. Актуализация проблемы формирования духовности связана с современными требованиями к моральным качествам взрослых, что следует из их особенной функции сообществе относительно возможностей влиять на формирование и становление духовных 
ценностей подрастающего поколения. Проведение психолого-педагогических семинаров, лекций, консультаций для взрослых относительно личных проблем, которые возникают вследствие непонимания или утраты главных моральных качеств человека, в режиме on-line является актуальным и востребованным. Формой такого общения предлагается рассмотреть вебинар, как один из инструментов применения информационно-коммуникационных технологий в неформальном образовании взрослых.

Ключевые слова: вебинар; духовно-моральные ценности; неформальное образование; образование взрослых; психологическое консультирование; психологический семинар.

\title{
FEATURES OF USING WEBINARS FOR DEVELOPMENT OF SPIRITUAL AND MORAL VALUES IN INFORMAL ADULTS EDUCATION
}

\author{
Iryna S. Pichuhina \\ graduate student \\ Institute of Information Technologies and Learning Tools of NAPS of Ukraine, Kyiv, Ukraine \\ Iryna_ryna@mail.ru
}

\begin{abstract}
The purpose of this article is to examine the features of using webinars for the development of spiritual and moral values in the non-formal adult education. Actualization of the problem of spirituality formation is associated with the modern requirements to moral features of adults arising from their special social function of influence on the formation of spiritual values of younger generation. Conducting psychological and educational on-line workshops, lectures, consultations for adults arising from problems of misunderstanding or loss of key moral features is relevant and demanded. As a form of such interaction the webinar is suggested as an ICT-tool used in non-formal adults education.
\end{abstract}

Keywords: webinar; spiritual and moral values; non-formal education; adult education; psychological consultation; psychological seminar.

\section{REFERENCES (TRANSLATED AND TRANSLITERATED)}

1. Belous I. Does Ukraine need a informal education? [online] / I. Belous // Student online magazine "Education and ...". - Available from: http://osvitata.com/osvita-ta-suspilstvo/chi-potribna-ukrani-neformalna-osvita.html. — Date of access 19.09.2014. (in Ukrainian)

2. Bylava U. L. Information Technology in Teaching of psychological profile / Bylava U.L. / The use of information technology and educational e-learningin high school: Materials Science Conference / ManagingeditorV.A. Snezhitsky. - Grodno: GrGMU, 2011. - P. 23-26. (in Russian)

3. Volchenska T. V. Formation of the spiritual master [online] / T. V. Volchenska/ Innovative vocational education: search by additions - Materials III All-Ukrainian scientific-practical onlineconferencededicatedto 20th anniversaryof NAPS ofUkraine (26-30 March 2012) — UMOPostgraduate Institute of Engineering teaching staff — Donetsk, 2012. - 340 p. - Available from : http://kafpppo.narod.ru/user-files/conference2012.pdf. — Date of access 23.03.2014. (in Russian)

4. GyseinovaE. I. Informal education asan important element of continuing education [online] / Gyseinova E. I., Luk'yanova U. M. // Pedagogical sciences: Strategic direction sofreforming of the education system-Sumskayanatsyonalny Agricultural University, 2012. - Available from : http://www.rusnauka.com/11_NPE_2012/-Pedagogica/4_106261.doc.htm. — Date of access 09.09.2013. (in Ukrainian)

5. Kleino L. G. Capabilities and features of carrying out of webinars [online] / Kleino L. G., Grinko V. O. // Scientific journal "Aspect" - International scientific and practical conference 2014 — Gosudrstveny University "Donbasky Derzhavny pedagogichny universitet" — Slov'yansk. — Available from : http://asconf.com/rus/index — Date of access 20.03.2014. (in Ukrainian)

6. Kodzhaspirova G. M. Pedagogical dictionary: for students of higher. and environments. ped. Textbook. Head. / Kodzhaspirova G. M., Kodzhaspirov A. Y. — Moscow : Academy, 2005. — 176 p. (in Russian) 
7. Luk'yanova L. B. Top features of ofadult education / L. B. Luk'yanova // Adult Education: Theory, Experience and Perspectives: collection of scientific papers. - K IPOOD APS ofUkraine, 2009. — Issue 1. - P. 97. (in Ukrainian)

8. Luk'yanova L. B. The socio-cultural function of adult education in modern society / L. B. Luk'yanova // Journal of University of Cherkassy. Series pedagogy. - 2010. — Issue 183, Part 1. - P. 6-12. (in Ukrainian)

9. Mugovuch S. M. Role of social networks in shaping educational and informative environment agrarian universities: Article / Mugovuch S. M., Tverezovska N. T. // Scientific Bulletin NUBiPseries "Pedagogy, Psychology, Philosophy." - Issue 175, Part 3. - Kyiv, 2012. — Mode of access: http://www.mnau.edu.ua/ua/02_02_01_10_mygovich.-html\#ixzz2wnSKAKKp. — Dateofaccess 25.05. 2014. (inUkrainian)

10. Place of psychology in human nature [online] / Website. - Available from : http://ua.convdocs.org/docs/index-184148.html. — Date of access 23.03.2014. (in Ukrainian)

11. Morze N. V. Methodological features of webinars as innovative learning technologies / Morze N. V., O. V. Ignatenko// Information Technology in Education: collection of scientific papers. Kherson : KSU, 2010-Issue 5. - P. 31-39. (in Ukrainian)

12. Nesterenko G. O. Modern socialnetworks as aninstrument of non-formal education / Nesterenko G. O., Tishkova O. V. // Gilea. Scientific Bulletin. — Issue 49 (№7). — 2011. — P. 451-458. (in Ukrainian)

13. Puskliarova A. V. Psychological training asaninnovativewayto educational work in higher education [online] / PuskliarovaA. V., Matsko L. A. / VinnytsiaNationalTechnicalUniversity. Available from : http://conf.vntu.edu.ua/humed/2010/txt/Pysklyarova_Matsko.php. _ Dateofaccess 22.03.2014. (in Ukrainian)

14. Practical psychologyas a scientific discipline [online] / Website. - Available from : http://knowledge.allbest.ru/psychology/2c0b65635b2bd68b4d53b88521216d27_0.html_ _ Dateofaccess 22.03.2014. (in Ukrainian)

15. Tkachova T. M. The development of spiritual culture of the individual teacher sinmethodology of educational institutions of the city: abstract. Ph.D. ... / Tkachova T. M. - Lugansk National Pedagogical University name dafterTaras Shevchenko. - Lugansk, 2004. - 23 c. (in Ukrainian)

16. Tsarenko V. O. Webinar technology asan educational collaboration of students and teachers in secondary schools / Tsarenko V. O. // Information Technology in Education: collection of scientific papers. - Kherson: KSU, 2011. - Issue 9. - P. 89-93. (in Ukrainian)

17. Shevchenko O. V. Spiritual education in modern family [online] / Shevchenko O. V. - Available from : http://vuzlib.com/content/view/968/94. — Date of access 10.09.2014. (in Ukrainian)

18. Whatis a Webinar? [online]. — Available from : http://web2.in.ua/2010/01/18/scho-takevebinar.html. — Dateofaccess 18.03.2014. (inUkrainian)

19. Yagupov V. V. Pedagogy: Tutorial [online] / Yagupov V. V. - K. : Lybed, 2002. — 560 c. Available from: http://eduknigi.com/ped_view.php?id=267. — Date of access 10.09.2014. 